\title{
THE USE OF STEM CELLS IN THERAPEUTIC TREATMENT PROCEDURES: LEGAL AND ETHICAL ASPECTS
}

\author{
Hennie Oosthuizen \\ Bluris LLB LLD LLD \\ Professor and Head \\ Department of Criminal and Medical Law \\ University of the Free State
}

\section{SUMMARY}

The use of stem cells in therapeutic treatment procedures involves both legal and ethical aspects. The law and medical ethics walk hand-in-hand in this regard. The tremendous progress and advances in biomedical research, as well as developments in new treatment procedures, are contributing to more and more successes in the healing process. A consequence of these new biomedical techniques and treatments is that the law, and especially legislative requirements, cannot keep up with such techniques and treatments. At this stage there is no legislation in force in South Africa to regulate the use of stem cells in the therapeutic treatment of patients. The South African Parliament promulgated the National Health Act 61 of 2003 a few years ago, but, as at the time of writing, the sections dealing with stem cells are still not in force. These sections permit the therapeutic cloning of human stem cells and, if it eventually comes into force, it will allow the therapeutic cloning of human stem cells for use to the benefit of patients, and will also assist practitioners. The legal and ethical aspects regarding the usage of stem cells in the therapeutic treatment of patients and not for research on stem cells, form the basis of this article. The discussion will include aspects such as stem cells and where they are derived from, patients' rights to choose to make use of stem-cell therapy, informed consent for stem cell treatment, the recognition of novel treatment procedures, the practitioner's scope of practice as well as legislative control to indicate the need for such control.

\section{INTRODUCTION}

The media frequently reports on new developments and treatment procedures used in medicine. Some of these new therapies are more controversial than others. One of the therapies which is currently being hotly debated and reported on, is the use of stem cells in therapeutic treatment procedures. Researchers from all over the world report almost daily on new successes in the curing and/or treatment of a wide variety of diseases using stem cells. Pepper ${ }^{1}$ states that excitement and expectations are generated by the many pre-clinical and early clinical studies that continue to reveal the

Pepper "The Stem Cell Regulatory Environment in South Africa - Case for Concern" July 2009 99(7) SA Medical Journal 505-507. 
enormous potential of regenerative medicine. According to reports the following diseases are currently treated: heart diseases, ${ }^{2}$ some blood disorders such as thalassaemia, Fanconi's anaemia and sickle-cell anaemia, cancers such as leukaemia and lymphoma, and metabolic and immune disorders. ${ }^{3}$ Extensive research is also being undertaken in the field of neurological diseases, for example ischaemia (strokes and cerebral palsy in young children ${ }^{4}$ ), spinal-cord injuries, demyelinating disease (multiple sclerosis), ${ }^{5}$ Alzheimer's disease and Parkinson's disease. ${ }^{6}$ The author is aware of the fact that there are a magnitude of fraudulent stem-cell research projects currently being done and also of the controversies regarding research on stem cells, but these issues will be dealt with in a future article.

In South Africa, practitioners are starting to use stem-cell therapy in a variety of treatment procedures. At this stage there is no legislation yet in force in South Africa that specifically regulates the use of stem cells in therapeutic, medical treatment procedures. The National Health Act 61 of 2003 (hereinafter "the National Health Act") (which came into force on 2 May 2005) will eventually provide for the utilization of stem cells and related matters. The sections dealing with these issues are to be found in Chapter 8 of the Act which, however, is not yet in force. ${ }^{7}$ Furthermore, two sets of draft regulations published in terms of the Act, and dealing with human stem cells and related matters, were, at the time of writing, also still in draft. ${ }^{8}$ The Human Tissue Act 65 of 1983 (hereinafter "the Human Tissue Act"), which can provide some assistance in this regard, was repealed by the National Health Act, but remains in force for the interim period ${ }^{9}$ until Chapter 8 is eventually operational.

In practice, medical practitioners, specialists or surgeons may already be using this new form of therapy in treating their patients. The following questions arise in this regard: May they make use of harvested stem cells or therapeutically cloned human stem cells in treating their patients? Is this ethically acceptable? Are doctors allowed to inform pregnant women of the advantages of storing the umbilical cord blood of their newborn babies? Are there guidelines and/or is there legislation in force to regulate the use of stem cells in the therapeutic treatment of their patients?

2 Jordaan, Woodrow and Pepper "Banning Private Stem Cell Banks: A Human Rights Analysis" 200925 SAJHR 126-151; and GN R7 of 2007-01-05.

3 Anonymous "Stem Cell Technology is a Fascinating, Evolving Science in Medical Circles" 9 July 2009 Krant 9.

$4 \quad$ Pepper July 2009 99(7) SA Medical Journal 505-507.

5 Holt "Neurological Disorders: A Focus on Stem Cells as Potential Treatment" January 2009 2(1) Neuron 12-13.

6 Swanepoel "A Proposed Legislative Framework for the Regulation of Aspects Pertaining to Embryonic Stem Cell Research and Therapeutic Cloning in South Africa" 2010 73(1) THRHR 1-23.

7 Slabbert and Oosthuizen "Shortcomings in Legislation and the Current System of Organ Procurement in South Africa" 2007 Obiter 304-323; and Pepper July 2009 99(7) SA Medical Journal 505-507.

8 Regulations regarding the use of human DNA, RNA, cultured cells, stem cells, blastomeres, polar bodies, embryos, embryonic tissue and small tissue biopsies for diagnostic testing, health research and therapeutics (GN R7 of 2007-01-05); and regulations relating to human stem cells (GN R 376 in GG 29840 of 2007-05-04).

9 Pepper July 2009 99(7) SA Medical Journal 505-507. 
To provide answers to these questions, this article will focus on the following aspects: (a) a brief discussion of what stem cells are and from where they are derived; (b) the relationship between the law and medical ethics, and, in particular, the patient's right to self-determination/autonomy, his or her right to informed consent, and the use of novel treatment procedures; (c) the relevant legislation and regulations; (d) the therapeutic cloning of human stem cells; and (e) the scope of practice of medical practitioners.

\section{WHAT ARE STEM CELLS AND FROM WHERE ARE THEY DERIVED?}

What do we understand by the term "stem cells"? Stem cells are in general being defined as undifferentiated cells that have the ability to self-replicate for indefinite periods into any cell type in the human body through the process of differentiation. ${ }^{10}$ The Draft Regulations relating to Human Stem Cells ${ }^{11}$ published in the Government Gazette for comment define stem cells as follows:

"Stem cells mean any embryonic stem cell, circulating progenitor cell, bone marrow progenitor cell including haemopoietic progenitor cell, umbilical cord progenitor cell, haemopoietic progenitor cell or any cell that is capable of replicating (proliferating) and giving rise to a differentiated cell."

The two sets of Regulations are still in draft form three years after being published on 5 January 2007 and 4 May 2007 respectively and are therefore used only as a guideline.

There are several sources from which stem cells can be derived, namely -

- human embryonic stem cells created by in vitro fertilization; ${ }^{12}$

- cadaveric fetal tissue or embryonic germ cells derived from human tissue after abortion; ${ }^{13}$

- cloned human embryos created by somatic cell nuclear transfer; ${ }^{14}$

- cloned chimera embryos created by introducing a human somatic cell into an enucleated animal ovum; ${ }^{15}$

Swanepoel 2010 73(1) THRHR 4.

1 Jordaan, Woodrow and Pepper 200925 SAJHR 126-151; Regulations regarding the use of human DNA, RNA, cultured cells, stem cells, blastomeres, polar bodies, embryos, embryonic tissue and small tissue biopsies for diagnostic testing, health research and therapeutics (GN R7 of 2007-01-05); and regulations relating to human stem cells (GN R 376 in GG 29840 of 2007-05-04).

12 Carstens and Pearmain Foundational Principles of South African Medical Law (2007) 191; Dhai, Moodley, McQuoid-Mason and Rodeck "Ethical and Legal Controversies in Cloning for Biomedical Research - A South African Perspective 200494 SA Medical Journal 906909; Swanepoel 2010 73(1) THRHR 6.

13 Carstens and Pearmain 191; Dhai, Moodley, McQuoid-Mason and Rodeck 200494 SA Medical Journal 906-909; Swanepoel 2010 73(1) THRHR 6.

14 Ibid.

15 Ibid. 
- adult cells obtained from the skin, blood, ${ }^{16}$ bone marrow ${ }^{17}$ and fat ${ }^{18}$ of live humans; and

- umbilical-cord blood obtained from a baby just after birth. ${ }^{19}$

Parents are nowadays increasingly being made aware of the advantages and importance of storing the umbilical-cord blood stem cells of their newborn babies for possible future use. ${ }^{20}$ Umbilical-cord blood can easily be collected at birth without any harm to mother or child. After the stem cells have been harvested/extracted from the cord blood, they are cryogenically frozen and stored at -196 degrees Celsius, preferably in a registered laboratory or umbilical-cord blood bank. There are already a few wellequipped laboratories and umbilical-cord blood banks in South Africa. Jordaan, Woodrow and Pepper ${ }^{21}$ indicate that there are currently three local private stem-cell banks. Medical practitioners should therefore encourage pregnant women to consider the advantages of this option.

\section{THE RELATIONSHIP BETWEEN THE LAW AND MEDICAL ETHICS}

We must always remember that the law and medical ethics walk, and work, hand-in-hand in all cases relating to medical intervention, treatment or research. The one cannot function without the other. In the use of stem cells for therapeutic purposes, for example, the following ethical issues are relevant: the patient's right to self-determination; his or her right to be informed and to give informed consent; and the use of novel treatment procedures. Each of these issues will be dealt with individually.

\section{The patient's right to self-determination/autonomy}

Consent by a patient to the performance of any form of medical treatment, be it therapeutic, non-therapeutic or diagnostic in nature, is currently generally accepted as a necessary prerequisite. ${ }^{22}$ Societies worldwide place a high premium on the individual's right to physical integrity and to selfdetermination. ${ }^{23}$ The patient's right to self-determination and the principle of a patient's autonomy are also recognized worldwide. ${ }^{24}$

19 Holt January 2009 2(1) Neuron 12-13; Jordaan, Woodrow and Pepper 200925 SAJHR 126151; Carstens and Pearmain 191; and Dhai, Moodley, McQuoid-Mason and Rodeck 2004 94 SA Medical Journal 906-909.

20 Jordaan, Woodrow and Pepper 200925 SAJHR 126-151.

21 Ibid.

22 Oosthuizen and Verschoor "Ethical Principles Becoming Statutory Requirements" 2008 50(6) SA Family Prac J 36-40; and Dhai "Informed Consent - 2008" June 2008 1(1) SA Journal for Bioethics and Law 27-30.

23 Strauss Doctor, Patient and the Law 3ed (1991) 1, 8, 420 and 422.

24 Claassen and Verschoor Medical Negligence in South Africa (1992) 57 and 76.
} 
The law in South Africa has not lagged behind in this regard. As early as 1923 our courts confirmed this principle. In the case of Stoffberg $v$ Elliot, ${ }^{25}$ recognition was given to the protection of the individual's personality and free will. ${ }^{26}$

In terms of the Constitution of the Republic of South Africa of 1996 (hereinafter "the Constitution"), every person has a right to selfdetermination. ${ }^{27}$ Section 12 of the Constitution deals with freedom and security of the person. Section 12(2) provides that every person has the right to bodily and psychological integrity, which includes the right to security in, and control over, their bodies and not to be subjected to medical, or scientific experimentation without their informed consent. ${ }^{28}$ McQuoid-Mason ${ }^{29}$ therefore correctly states that a patient's autonomy is recognized in the Constitution.

The National Health Act also provides, in section 7, that a person cannot be treated without his or her co-operation and consent. ${ }^{30}$ Both the Constitution and the National Health Act make this a statutory requirement that must be complied with. Furthermore, we must not forget that the common law also recognizes a patient's right to self-determination. ${ }^{31}$

It is thus clear that, when a patient freely and voluntarily chooses a specific treatment procedure, for example stem-cell therapy, he or she is exercising his or her common law as well as constitutional right to his or her bodily integrity and security, ${ }^{32}$ that is, his or her right to self-determination.

\section{Informed consent by the patient}

As stated above, informed consent is a prerequisite for any form of medical treatment. ${ }^{33}$ In general, a person is capable of giving informed consent if he or she is compos mentis, that is, has the necessary mental capacity to understand the nature and consequences of his or her actions. ${ }^{34}$ Dhai $^{35}$ states that "capacity to give consent" refers to both legal and mental capacity.

251923 CPD 148.

26 Oosthuizen and Verschoor 2008 50(6) SA Family Prac J 36-40; and Dhai June 2008 1(1) SA Journal for Bioethics and Law 27-30.

$27 \quad \mathrm{~S} 12$.

28 Oosthuizen and Verschoor 2008 50(6) SA Family Prac J 36-40; and Dhai June 2008 1(1) SA Journal for Bioethics and Law 27-30.

29 McQuoid-Mason "An Introduction to Aspects of Health Law: Bioethical Principles, Human Rights and the Law" June 2008 1(1) SA Journal for Bioethics and Law 7-10.

30 lbid.

31 Oosthuizen and Verschoor 2008 50(6) SA Family Prac J 36-40; Dhai June 2008 1(1) SA Journal for Bioethics and Law 27-30; and McQuoid-Mason June 2008 1(1) SA Journal for Bioethics and Law 7-10.

32 Ibid.

33 Oosthuizen and Verschoor 2008 50(6) SA Family Prac J 36-40; and Dhai June 2008 1(1) SA Journal for Bioethics and Law 27-30.

34 Strauss and Strydom Die Suid-Afrikaanse Geneeskundige Reg (1967) 176, 182, 182-186 and 189.

35 Dhai June 2008 1(1) SA Journal for Bioethics and Law 27-30. 
In terms of the ethical requirements for valid consent, a patient must be informed about -

- the nature and consequences of the treatment;

- the risks associated with the intervention;

- the diagnosis.

The above three ethical requirements are now statutorily laid down in the National Health Act, which stipulates, in section 6(1), that the provider of health care must inform the user (patient) of $-{ }^{36}$

- the user's health status,

- the general diagnostic procedures and treatment options available,

- the general associated advantages, risks, costs and consequences of the options, and

- the user's right to refuse health-care services and provide him or her with an explanation of the implications, risks and obligations of such refusal.

Section 6(2) of the National Health Act further stipulates that the provider of health-care services must inform a user, in a language that he or she understands and in a way that takes his or her level of literacy into consideration, of the aspects referred to in section 6(1). Section 7 determines that a user may not be provided with health services without his or her informed consent. ${ }^{37}$

A user has the right, according to section 8 of the National Health Act, to participate in the decisions. Section 8(1) stipulates that a user has the right to participate in any decision affecting his or her personal health and treatment. Section 8(2)(a) stipulates that, if the informed consent required by section 7 is given by a person other than the user, such person must, if possible, consult the user before giving the required consent. Section 8(2)(b) provides that, if a user is capable of understanding the relevant procedure, he or she must be informed as contemplated in section 6 , even if he or she lacks the legal capacity to give the informed consent required by section 7 . If a user is unable to participate in a decision affecting his or her personal health and treatment, section 8(3) provides that he or she must be informed as contemplated in section 6 after the provision of the health service in question, unless the disclosure of such information would be contrary to the user's best interests. In terms of the common law, a patient also has a right to give consent before treatment may begin or take place. ${ }^{38}$

The Draft Regulations ${ }^{39}$ also provide a definition of informed consent, which definition reads as follows:

36 Oosthuizen and Verschoor 2008 50(6) SA Family Prac J 36-40; Dhai June 2008 1(1) SA Journal for Bioethics and Law 27-30; and McQuoid-Mason June 2008 1(1) SA Journal for Bioethics and Law 7-10.

37 Ibid.

38 McQuoid-Mason June 2008 1(1) SA Journal for Bioethics and Law 7-10.

39 Regulations regarding the use of human DNA, RNA, cultured cells, stem cells, blastomeres, polar bodies, embryos, embryonic tissue and small tissue biopsies for diagnostic testing, health research and therapeutics (GN R7 of 2007-01-05); and regulations relating to human stem cells (GN R 376 in GG 29840 of 2007-05-04). 


\begin{abstract}
"Informed consent means an agreement whereby a participant, donor or health-care user voluntarily confirms his or her willingness to participate in research, donation or treatment, after understanding all aspects of such research, donation or treatment that are relevant to his or her decision."
\end{abstract}

Informed consent by a patient can be given either expressly, that is, verbally or in writing, or impliedly by way of conduct, that is, tacitly. Medical practitioners, specialists or surgeons must, however, ensure that they obtain written, informed consent from the patient before any surgical or complex procedures take place.

It is thus also clear that, as regards informed consent, the ethical principles go hand-in-hand with the legislative requirements.

\title{
33 Novel treatment procedures
}

That stem cells can be used in the therapeutic treatment of patients is a wellknown fact worldwide in the medical profession. Researchers are already using and developing stem cells in a wide variety of treatments for diseases,${ }^{40}$ with a high success rate.

Novel treatment procedures should not be hampered by viewpoints that there is no proof that they will be successful. Decades ago, the first heart was transplanted by $\mathrm{Dr}$ Chris Barnard, yet nobody knew beforehand precisely what the consequences would be. The same applies with regard to kidney and other transplant procedures that followed.

Novel treatment procedures must not be confused with experimental procedures. Claassen and Verschoor ${ }^{41}$ state that in no other profession is there a greater need for continual progress than in medicine, and, that it is therefore unavoidable that a measure of experimentation will prevail during the development of new methods of treatment. Strauss ${ }^{42}$ also indicates that the necessity for some experimentation on humans for the sake of advancement in medical science, be recognized.

In cases where there is no other recognized treatment available for the practitioner to use on his or her patients, he or she will most definitely be confronted by the decision whether to use a novel treatment procedure like stem-cell therapy or not to treat the patient at all. ${ }^{43}$

Strauss ${ }^{44}$ is of the opinion that responsible medical experimentation based on sound scientific hypotheses, which is therapeutic in nature and in the direct, potential interest of the patient, is lawful, provided that the necessary informed consent has been obtained.

Ethically and legally, novel treatment procedures may thus be used in the following circumstances:

\footnotetext{
Jordaan, Woodrow and Pepper 200925 SAJHR 126-151; Anonymous 9 July 2009 Krant 9; and Holt January 2009 2(1) Neuron 12-13.

41 Claassen and Verschoor 57.

42 Strauss 1, 8, 420 and 422.

43 Claassen and Verschoor 57.

44 Strauss 1, 8, 420 and 422.
} 
- in cases where there are no other known treatment procedures;

- in cases where there is no prejudice to the patient;

- in cases where the patient gives informed consent for the use of such treatment procedures.

\section{LEGISLATION AND REGULATIONS}

There are two pieces of legislation that are applicable to the use of stem cells in the therapeutic treatment of patients, namely the Human Tissue Act and the National Health Act. Whenever any tissue is removed from the body of a living human being in order to create stem cells, informed consent must be obtained to do so.

\section{The Human Tissue Act 65 of 1983}

The Human Tissue Act, which was repealed by the National Health Act, will, for the interim period ${ }^{45}$ still regulate certain aspects regarding human tissue and related matters. ${ }^{4 \hat{6}}$

The Human Tissue Act contains stipulations that can be made applicable to stem cells and the use thereof in medical treatment. Sections 18, 19 and $39 \mathrm{~A}$ of the Human Tissue Act need to be considered in the handling of embryonic stem cells.

Section 39A of the Act deals with genetic manipulation and reads as follows:

"Notwithstanding anything to the contrary contained in this Act or any other

law, no provision of this Act shall be so construed as to permit genetic

manipulation outside the human body of gametes or zygotes."

The section clearly prohibits genetic manipulation of gametes and zygotes outside the human body. If no gametes or zygotes are genetically manipulated in the creation of stem cells or embryonic stem cells, section 39A will not be applicable.

Section 18 deals with consent to remove tissue from the body of a living person. ${ }^{47}$ Written informed consent by a major is a requirement and for minor persons, their parents or guardians need to give written consent.

45 Pepper July 2009 99(7) SA Medical Journal 505-507; and Slabbert and Oosthuizen 2007 Obiter 304-323.

46 Swanepoel 2010 73(1) THRHR 8-9.

47 S 18 reads as follows:

"No tissue, blood or gamete shall be removed or withdrawn from the body of a living person for a purpose referred to in section $19-$

(a) Except in accordance with the prescribed conditions; and

(b) Unless written consent thereto has been granted -

(i) where such a person is a major, by that person;

(ii) where such a person is a minor, by the parents or guardians of that person: Provided that -

(aa) in the case of the removal of tissue which is replaceable by natural processes, or the withdrawal of blood, from the body of a person who is a competent 
Section 19 deals with the purposes for which tissue from the bodies of living persons may be used. ${ }^{48}$ Only in cases where the placenta, fetal tissue or the umbilical cord is used to create embryonic stem cells is it necessary to obtain the consent of the Minister of Health to remove or use such tissue.

\section{The National Health Act 61 of 2003}

Sections 55 and 56 in Chapter 8 of the National Health Act, which have not yet come into operation, ${ }^{49}$ contain similar requirements as above regarding the patient's written consent for the removal of tissue and the use of tissue.

Section 55 is similar to section 18 of the Human Tissue Act. In terms of section 55 tissue, blood, a blood product or gametes may not be removed from the body of a living person if the written informed consent of that specific person has not been obtained according to the prescribed manner and in accordance to the prescribed conditions. ${ }^{50}$

The same can be said regarding section 56 and section 19 of the Human Tissue Act. Section 55(1) stipulates that a person may only use tissue, blood, blood products or gametes for medical and dental purposes as prescribed. ${ }^{51}$ The Minister may authorize the removal or withdrawal of tissue,

witness, the consent of that person to the removal of that tissue or blood shall be sufficient, whether it be granted in writing or orally;

(bb) tissue removed in the interest of his health from the body of a living person with his consent or with the consent of any other person who may in law give consent on his behalf, may be used for any of the purposes referred to in section 19."

48 S 19 reads as follows:

"Any tissue, blood or gamete removed or withdrawn from the body of a living person shall, subject to the regulations, only be used for medical or dental purposes, including -

(a) in the case of such tissue, the use or transplanting thereof in the body of another living person or for the production of a therapeutic, diagnostic or prophylactic substance;

(b) in the case of such blood, the administering thereof to another living person or the production of a blood product; and

(c) in the case of such gamete, the artificial fertilization of another person:

Provided that -

(i) any tissue, blood or gamete of a person who is mentally ill within the meaning of the Mental Health Act, 1973 (Act 18 of 1973); or

(ii) any tissue of a person who is a minor and which is not replaceable by natural processes or any gamete of any such person; or

(iii) any gamete of a person who has been declared a habitual criminal in terms of section 286 of the Criminal Procedure Act, 1977 (Act 51 of 1977);

(iv) placenta, foetal tissue and umbilical cord, except with the consent of the Minister and subject to any condition mentioned in the consent,

shall not be used for any of the purposes referred to in paragraph (a), (b) or (c) of this section."

49 Pepper July 2009 99(7) SA Medical Journal 505-507.

50 S 55 reads as follows:

"A person may not remove tissue, blood, a blood product or gametes from the body of another living person for the purpose referred to in section 56 unless it is done -

(a) with the written consent of the person from whom the tissue, blood, blood product or gametes are removed granted in the prescribed manner; and

(b) in accordance with prescribed conditions.

51 S 56 reads as follows: 
blood, a blood product or gametes.

\section{THE THERAPEUTIC CLONING OF HUMAN STEM CELLS}

As mentioned above, there are several sources from which stem cells can be derived, one of which is the therapeutic cloning of stem cells. In order to create enough stem cells for therapeutic use, it is sometimes necessary to create them by way of cloning. The National Health Act contains stipulations regarding stem cells and research on stem cells. The relevant sections are not yet in force, but, as they were promulgated together with the Act, they can be used as guidelines to solve problems in practice where there is an absence of legislative guidance. The Draft Regulations ${ }^{52}$ can also be used as guidelines.

There are two forms of cloning human cells:

- reproductive cloning: In terms of section 57(6)(a), reproductive cloning of a human being means the manipulation of genetic material in order to achieve the reproduction of a human being and includes nuclear transfer or embryo splitting for such purpose;

- therapeutic cloning: In terms of section 57(6)(b), therapeutic cloning means the manipulation of genetic material from either adult, zygotic or embryonic cells in order to alter, for therapeutic purposes, the function of cells or tissues.

Cloning, and especially human cloning, is a very controversial topic. ${ }^{53}$ Worldwide, there is a ban on the reproductive cloning of human beings. ${ }^{54}$ Section 57(1) of the National Health Act also prohibits reproductive human cloning. Section 57(1) of the Act reads as follows:

"A person may not -

(1) A person may use tissue or gametes removed or blood or a blood product withdrawn from a living person only for such medical or dental purposes as may be prescribed.

(2)(a) Subject to paragraph (b), the following tissue, blood, blood products or gametes may not be removed or withdrawn from a living person for any purpose contemplated in subsection (1):

(i) Tissue, blood, a blood product or a gamete from a person who is mentally ill within the meaning of the Mental Health Care Act, 2002 (Act 17 of 2002);

(ii) tissue which is not replaceable by natural processes from a person younger than 18 years:

(iii) a gamete from a person younger than 18 years; or

(iv) placenta, embryonic or foetal tissue, stem cells and umbilical cord, excluding umbilical cord progenitor cells.

(b) The Minister may authorise the removal or withdrawal of tissue, blood, a blood product or gametes contemplated in paragraph (a) and may impose any condition which may be necessary in respect of such removal or withdrawal."

Regulations regarding the use of human DNA, RNA, cultured cells, stem cells, blastomeres, polar bodies, embryos, embryonic tissue and small tissue biopsies for diagnostic testing, health research and therapeutics (GN R7 of 2007-01-05); and regulations relating to human stem cells (GN R 376 in GG 29840 of 2007-05-04).

53 Carstens and Pearmain 191.

54 Ibid; and Swanepoel 2010 73(1) THRHR 9. 
(a) manipulate any genetic material, including genetic material of human gametes, zygotes or embryos, or

(b) engage in any activity, including nuclear transfer or embryo splitting, for the purpose of the reproductive cloning of a human being."

Section 57(1) will not be applicable in cases where embryonic stem cells are created for therapeutic purposes in order to treat patients.

The rest of section 57 deals with therapeutic cloning and research on stem cells. ${ }^{55}$ The Minister may permit therapeutic cloning utilizing adult or umbilical-cord stem cells. Contravention or non-compliance to the provisions of section 57 is an offence.

In terms of section 68 of the National Health Act, the Minister of Health may promulgate regulations on a variety of matters. Section 68 reads as follows:

“(1) The Minister may make regulations regarding -

(p) the acquisition, storage, harvesting, utilization or manipulation of tissue, blood, blood products, organs, gametes, oocytes or human stem cells for any purpose."

As stated above, the Regulations ${ }^{56}$ dealing with stem cells are at this stage only in draft form. However, like the sections of the Act that are not yet in force, they can also be used as guidelines.

\section{THE PRACTITIONER'S SCOPE OF PRACTICE}

Each and every speciality in medicine has a different scope of practice. The use of stem-cell therapy will therefore depend on the field of speciality and on experience. The Guidelines for Good Practice in Medicine, Dentistry and Medical Science of the Medical and Dental Professions Board of the Health Professions Council of South Africa provide specifically for the performance of professional acts. Booklet 3 deals with the Ethical and Professional Rules of the Medical and Dental Professions Board and Rule 21 thereof reads as follows:

55 S 57(2)-(5) reads as follows:

"(2) The Minister may, under such conditions as may be prescribed, permit therapeutic cloning utilizing adult or umbilical-cord stem cells.

(3) No person may import or export human zygotes or embryos without the prior written approval of the Minister.

(4) The Minister may permit research on stem cells and zygotes which are not more than 14 days old on a written application and if -

(a) the applicant undertakes to document the research for record purposes; and

(b) prior consent is obtained from the donor of such stem cells or zygotes."

(5) Any person who contravenes a provision of this section or who fails to comply therewith is guilty of an offence and is liable on conviction to a fine or to imprisonment for a period not exceeding five years or to both a fine and such imprisonment.

56 Regulations regarding the use of human DNA, RNA, cultured cells, stem cells, blastomeres, polar bodies, embryos, embryonic tissue and small tissue biopsies for diagnostic testing, health research and therapeutics (GN R7 of 2007-01-05); and regulations relating to human stem cells (GN R 376 in GG 29840 of 2007-05-04). 
“(1) A practitioner shall only perform, except in an emergency, a professional act for which he or she is adequately qualified and sufficiently experienced.

(2) A practitioner shall only perform, except in an emergency, a professional act under proper conditions and in appropriate surroundings."

What about the use of novel treatment procedures? Can stem-cell therapy be seen as a novel treatment procedure? The use of stem-cell therapy may indeed be seen as a novel treatment procedure, depending on the facts of a specific case. I am of the opinion that such therapy will be legally as well as ethically acceptable if it is performed in accordance with the stipulations stated above. If a practitioner is adequately qualified and sufficiently experienced, a novel treatment procedure will not be regarded as a transgression of any ethical rules. The same will be true for the prerequisite that the practitioner must perform his or her professional act under proper conditions and in appropriate surroundings.

\section{$7 \quad$ CONCLUSION}

The use of stem cells in therapeutic treatment procedures is here to stay. From the above discussion of the relevant aspects and sections of the Human Tissue Act and the National Health Act, it is clear that the removal and use of stem cells in therapeutic treatment procedures are legal and ethical and are not prohibited in South Africa. Therapeutic cloning of stem cells is also not prohibited and will be clearly regulated when the relevant sections of the National Health Act, as well as the regulations, come into operation.

Stem-cell therapy, and the successes obtained with such treatment, has progressed considerably in the past few years, but there is still much to be learnt. ${ }^{57}$ Researchers seem to be very optimistic and are of the opinion that stem-cell therapy will play a significant part in future treatment procedures.

57 Anonymous 9 July 2009 Krant 9. 